\title{
EWRITING ABSTRACTS IN THE UNIVERSITY \\ CONTEXT: COMBINING GENRE-BASED AND \\ PROCESS-ORIENTED APPROACHES
}

\section{ESCRITA DE ABSTRACTS NO CONTEXTO UNIVERSITÁRIO: A COMBINAÇÃO DAS ABORDAGENS VIA GÊNEROS TEXTUAIS E ESCRITA COMO PROCESSO}

\section{Reinildes Dias*}

\begin{abstract}
Abstracts play an essential role in the academic field since they are the first section of a research article readers have at their disposal to determine its relevancy. Their main goal is to give a concise view of the articles that accompany them. Grounded on recent theoretical studies, this paper discusses the principles of a pedagogical learning cycle that can assist students in the development of their academic writing literacies in English. This cycle combines two methodologies traditionally used to develop writing literacies, the process-oriented approach and the genre-based one. Additionally, it presents classroom practices developed for the university context regarding the teaching of the academic genre "abstract" to undergraduates taking English at a Faculty of Letters in a public university of Minas Gerais. The participants were freshmen who were taking English One, in their first term in the context of higher education. The classes took place in September of 2017 and ran for one third of a sixty-hour mandatory course. They were aimed at discussing the stages of the learning cycle to help students' understanding of how to write abstracts in English. The learning activities are thoroughly explained to demonstrate how the stages can be pedagogically applied to teaching practices. A brief analysis of one of the abstracts written by a participating group is given to show that the learning cycle can work well in assisting university students to adequately write abstracts. In a world where English is the major means of sharing scientific knowledge among members of academia, this writing pedagogy may be useful to learners in the process of composing abstracts in English as well as to professors teaching writing in the university context.
\end{abstract}

Keywords: abstract; combined approach; writing in English.

\section{RESUMO}

Os resumos acadêmicos desempenham um papel essencial no contexto de publicação, pois são a primeira seção de um artigo de pesquisa que os leitores têm à disposição para determinar sua relevância. Seu principal objetivo é fornecer uma visão concisa dos artigos que os acompanham. Com base em estudos teóricos recentes, este artigo discute os princípios de um ciclo pedagógico de aprendizagem que pode auxiliar alunos no desenvolvimento de seu

\footnotetext{
* Universidade Federal de Minas Gerais, UFMG, Belo Horizonte, MG, Brasil. reinildes@gmail.com Orcid: https://orcid.org/0000-0001-6140-463X
} 
letramento acadêmico, especialmente no processo de escrita em inglês. Este ciclo combina duas metodologias tradicionalmente usadas no desenvolvimento da escrita acadêmica, a abordagem orientada a processos e a baseada em gêneros. Além disso, apresenta práticas de sala de aula desenvolvidas para o contexto universitário em relação ao ensino do gênero acadêmico "abstract" para estudantes de graduação em inglês na Faculdade de Letras de uma universidade pública de Minas Gerais. Os participantes eram calouros que estavam cursando English One, em seu primeiro semestre no contexto do ensino superior. As aulas ocorreram em setembro de 2017 e duraram um terço de um curso obrigatório de sessenta horas. Elas tinham como objetivo discutir as etapas do ciclo de aprendizagem para a escrita de resumos em inglês. As atividades de aprendizagem são detalhadamente explicadas para demonstrar como elas podem ser aplicadas às práticas de ensino. Uma breve análise de um dos resumos escritos por um grupo participante é apresentada para demonstrar que o ciclo de aprendizagem pode funcionar para ajudar alunos universitários a escreverem resumos adequadamente. Em um mundo em que o inglês é o principal meio de compartilhar conhecimento científico entre os membros da academia, essa pedagogia de escrita pode ser útil para os alunos no processo de compor resumos em inglês, bem como para os professores que lecionam cursos de escrita acadêmica no contexto universitário.

Palavras-chave: abstract; abordagem combinada; escrita em inglês.

\section{INTRODUCTION}

In this paper I will discuss a pedagogical practice regarding the use of a writing learning cycle that combines genre-based and process-oriented approaches in the process of teaching the academic genre "abstract" to language undergraduates. My main goal is to weave cross-disciplinary theoretical views of language and literacies to the teaching of writing concerning the use of this pedagogical learning cycle I redesigned from the one created before (DIAS, 2004). I intend to highlight the importance of learners' awareness of the cyclical stages in the writing process and their understanding of what an abstract is, why it is written and its main roles. I will discuss the purposes of each of the stages learners have to go through in order to write an abstract. Students who participated in the teaching practice discussed in this paper were ten freshmen that were taking English One in their first semester at the Federal University of Minas Gerais (acronym in Portuguese: UFMG). After understanding the cyclical stages and showing a control of the ways abstracts are composed, the participants were asked to write their own versions of the genre.

First, I will briefly survey some studies about writing in English as a foreign / additional language. Then I will provide an overall view of social semiotics and the notion of multimodality to show that meanings in texts are expressed in an ensemble of semiotic modes. Then, I will showcase the stages of the learning cycle and some of the generic features of abstracts that will be of assistance in the students' process of composing them. Finally, I will analyze one of the abstracts written by a group 
of participating students to provide evidence of its adequacy concerning the use of both the rhetorical moves acknowledge by Hyland (2000, p. 67) and the semiotic modes closely associated with this genre. My ultimate goal is to bridge research and pedagogical practice on behalf of the combined approach that seems suitable to support university students in the process of writing well-formed and appropriate abstracts in English.

\section{BRIEF REVIEW OF THE LITERATURE}

In this section, I will give an overall view of the two traditional approaches related to the teaching of writing in English as a foreign / additional language. Next, I will briefly contrast them and then I will focus on the combined approach that I have been using in my teaching practices. Finally, my attention will be centered on the academic genre "abstract" and its generic characteristics to review current literature about this genre, the focus of interest in this paper.

\subsection{The process-oriented approach}

It is now almost thirty years since White and Arndt (1991) unveiled important information about the process of writing based on their own and their predecessors' research (RAIMES, 1983; BEREITER; SCARDAMALIA, 1987, among others). At the time, they acknowledged that

$[w]$ riting is a form of problem-solving which involves such processes as generating ideas, discovering a 'voice' with which to write, planning, goal-setting, monitoring and evaluating what is going to be written as well as what has been written, and searching for language with which to express exact meanings (p. 3). 


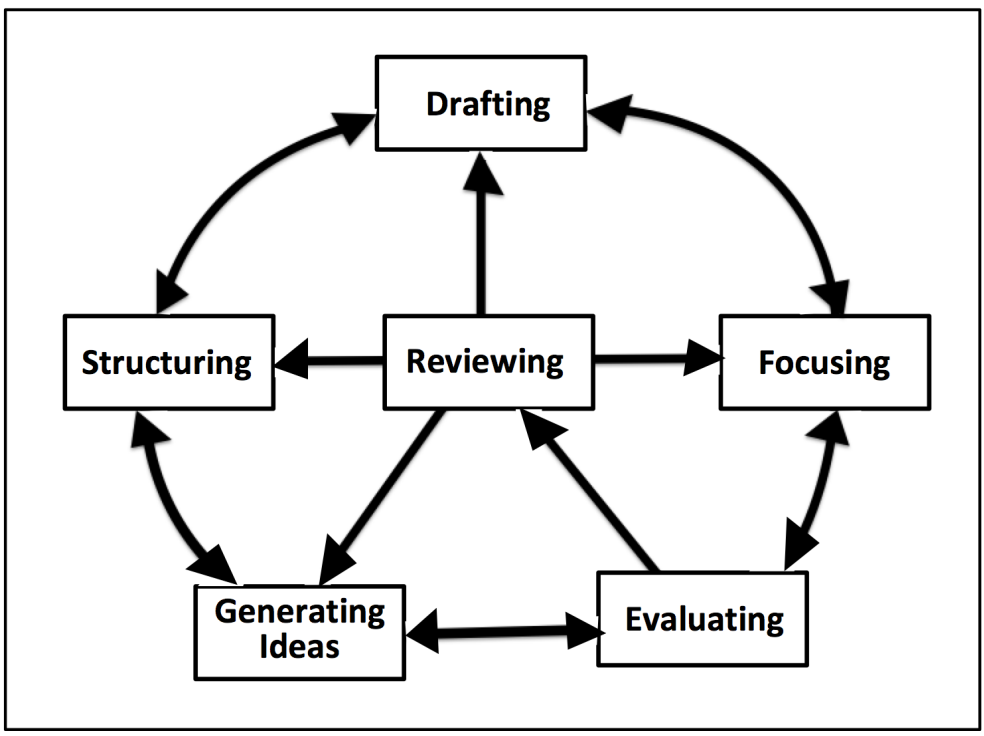

Figure 1. A model of writing (WHITE; ARNDT, 1991, p. 43)

Their well-known model (Fig. 1) depicts the "complex and recursive nature of writing" (p. 4), showing that it is neither a linear process nor a single-draft version of a text for publication. They recognize that writers have to deal with a "complex management problem" [...] that makes them "dart back and forth from one process to another in real time" (p. 4). Decisions writers have to make are challenging at all levels, "whether at the level of ideas, of planning, of organizing or of expression". Additionally, these processes occur simultaneously "with one influencing another", making the task of teaching writing a demanding endeavor. At its core prevail these intertwined aspects of language use: complexity, recursiveness, flexibility, selfregulation, uncertainty and imprecision (MORIN, 2011).

As White and Arndt (1991) acknowledge, generating ideas is usually the first stage in writing although it can occur later in the other stages due to the recursive nature of their model. Some of the strategies they suggest for this stage are: brainstorming, asking questions to stimulate thinking and the use of visuals. The focusing stage refers to decisions concerned with purpose, audience and text structure or form, a phase that is strictly related to rhetorical structuring although the researchers overlook the concept of genre and corresponding multimodal features. The drafting process marks the move to the "write-revise-rewrite cycle" that can trigger other stages for text improvement so as to generate other ideas, to improve text structure and to shape what had been done during focusing. Re-viewing and 
evaluating are closely related since writers' main concern during these processes is to assess the underlying coherence of what they are composing. Self-assessment and responding to each other's work are key strategies for text improvement during these writing stages. White and Arndt (1991) remind us that "by learning to evaluate others' writing, and responding in turn to evaluation of their own, [writers] will gradually build up that capacity for self-assessment, $[\ldots]$ a vital element in the process of writing (p.117). Writers are thus problem-solvers that read, exchange ideas, make decisions, respond to and discuss each other's work in the process of composing texts. Although useful in supporting students through the "writerevise-rewrite-evaluate" cycle, process-oriented approaches tend to "neglect the social consequences of writing and the purposes of communication in the real world where writing matters" (HYLAND, 2008, p. 10).

\subsection{The genre-based approach}

In genre-oriented practices writing is seen as a social recursive process to express meanings well fitted to particular sociocultural contexts for real purposes and audiences. This approach also takes into account that meaningful language interactions are only carried out through genres. Echoing Bakhtin (2003), Hyland (2004, p.64) emphasizes that "without the familiar structure that genres give to social events, we would be unable to conduct the most basic [verbal] interactions of everyday life". Even contemporary genres, influenced by digital technologies, can be readily recognized as an e-mail message, an infographic, a blog or a webpage, for example. We can immediately respond to them and to their multimodal arrangements and create similar ones if we need to. By increasing knowledge on the social conventions of genres, students can best develop relationships, establish communities, and achieve their communicative goals when writing in the English language.

\subsection{Process-oriented approaches versus genre-based ones}

Process-oriented writing tasks, for example, are based on topics such as, Life in cities, Eating babits and dieting, Noisy neigbbors and guidelines are not given about the way and for whom texts should be written. Writing from this perspective is viewed as an "asocial process" (HYLAND, 2008, p.9), relying only on the cognitive functioning of the mind. Furthermore, from their proponents' viewpoints, students are simply invited to choose topics to write about without considering the real purpose of their writings and the specific multimodal organization of texts they 
will compose. Genre-focused writing practices, however, take into account that students are familiar with different kinds of multimodal organizations of genres in their native language and this knowledge can help them achieve their communicative purposes when writing in English. Genre-based approaches emphasize that we only use language for communication so as to achieve communicative purposes for a particular social context.

Different from process-oriented approaches, instructions for writing activities from a social perspective (Fig.2) are based on the fact that "people don't just write, they write to achieve some purpose," following certain social conventions for organizing messages (HYLAND, 2004, p. 80). The relevant point is that these conventions can be learned and internalized by students so as to enhance their repertoire of different genres' composing ways and respective social demands. This way they will be able to write in English according to their personal or academic needs, following the conventions of the social domain their texts belong to.

\section{WRITING}

What to write: A short opinion essay.

Purpose: To comment on the digital tools you use for learning and for fun, give examples, and give your opinion about how adequate / useful they are.

Audience: Your classmates and teacher(s).

Figure 2. Instructions from a genre-based perspective (DIAS et al., 2018b, p. 134).

\subsection{The academic genre abstract}

Recent research on the academic genre "abstract" and corresponding classroom practices for teaching it - usually in higher education - follow a genre perspective epistemology (CANi KARABACAK, QIN, 2016; CHALAK NOROUZI, 2013; HYLAND, 2004; 2007; 2008; SWALES; FEAK, 2009). These studies have focused on the rhetorical organization of abstracts in terms of their structural moves and linguistic features, their purposes and educational value in the university setting although almost nothing has yet been written about their multimodal features. Abstracts are viewed as a key written composition for "being advance indicators of the content and structure of the following text" (SWALES, 1990, p. 179). They are also "a description or factual summary of the much longer report, and is meant to give the reader an exact and concise knowledge of the full article" (BATHIA, 1993, p. 78). 
Most research studies on this genre have identified a "potential total of five [rhetorical] moves" (SWALES; FEAK, 2009, p.5) although not all of them are always present in the abstracts that summarize studies in the field of Applied Linguistics (CAN; KARABACAK; QIN, 2016; CHALAK; NOROUZI, 2013; TSENG, 2011). According to Hyland (2000, p. 67), the possible five moves are as follows.

Table 1. Rhetorical moves and their functions in abstracts (HYLAND, 2000, p. 67)

\begin{tabular}{ll}
\hline Moves & Functions \\
\hline Introduction & Establishes context of the paper and motivates the research or discussion. \\
Purpose & $\begin{array}{l}\text { Indicates purpose, thesis or hypothesis, outlines the intentions behind the } \\
\text { paper. } \\
\text { Method }\end{array}$ \\
Product & $\begin{array}{l}\text { States main findings or results, the argument or what was accomplished. } \\
\text { Conclusion }\end{array}$ \\
\hline
\end{tabular}

Research undergone by Tseng (2011) on abstracts regarding articles in the field of Applied Linguistics revealed that moves tended to be structured in a four-move sequence (Purpose-Method-Product-Conclusion). The first move was usually the statement indicating the purpose behind the paper. The introduction or background information about the article context (rhetorical move 1) is most often omitted. More recently, academic investigation on the same topic developed by Can, Karabacak, and Qin (2016) yielded similar results. According to these researchers, "authors [applied linguists] discuss results, purpose, and methodology in their abstracts more than [...] background information" (p.14). Their study also showed that "implications of results [move 5] are conventional, appearing in most

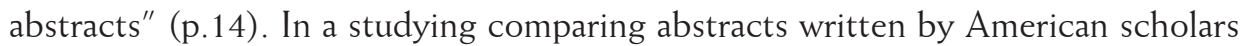
and Iranian ones (CHALAK $i$ NOROUZI, 2013), data analysis revealed that the rhetorical moves two, three and four (purpose, method and product respectively) were present in both sets of data. However, the other two, introduction (background information) and conclusion, were present in less than half of the abstracts analyzed, suggesting they seem to be optional moves.

In general, the present time is most common in certain moves, while the simple past prevail in others in the abstracts that summarize research articles in the field of Applied Linguistics (TSENG, 2011).

More recently, the theory of social semiotics and its correlated multimodal approach (KRESS, VAN LEEUWEN, 2006) have impacted the present view of 
language, giving emphasis to its social nature and cultural histories in addition to the integrated ensembles of different semiotic modes for intended communicative purposes. Over the last decade, researchers have been acknowledging that the verbal mode of representation is not the only one in the composition of genres and very often not the most important. Other semiotic modes, such as, visual, auditory, gestural, and spatial come into play in the process of composing texts (KRESS, VAN LEEUWEN, 2006). Writers can choose from a varied set of semiotic resources (e.g. colors and images from the visual mode, typefaces and sizes, bolding, italics, line thickness from the typography mode, etc.) to express meanings (Fig. 3). This phenomenon is closely related to digital technologies whose affordances allow writers to effectively put together resources from different semiotic modes to create multimodal genres. Abstracts, for instance, are multimodal ensembles that mainly incorporate the verbal mode but also others as, for example, typography and its resources as, for instance, capital letters, different fonts and sizes, italics, bold. The spatial mode is also used: Abstracts are always located in the top of the page / screen just below the title, followed by keywords.

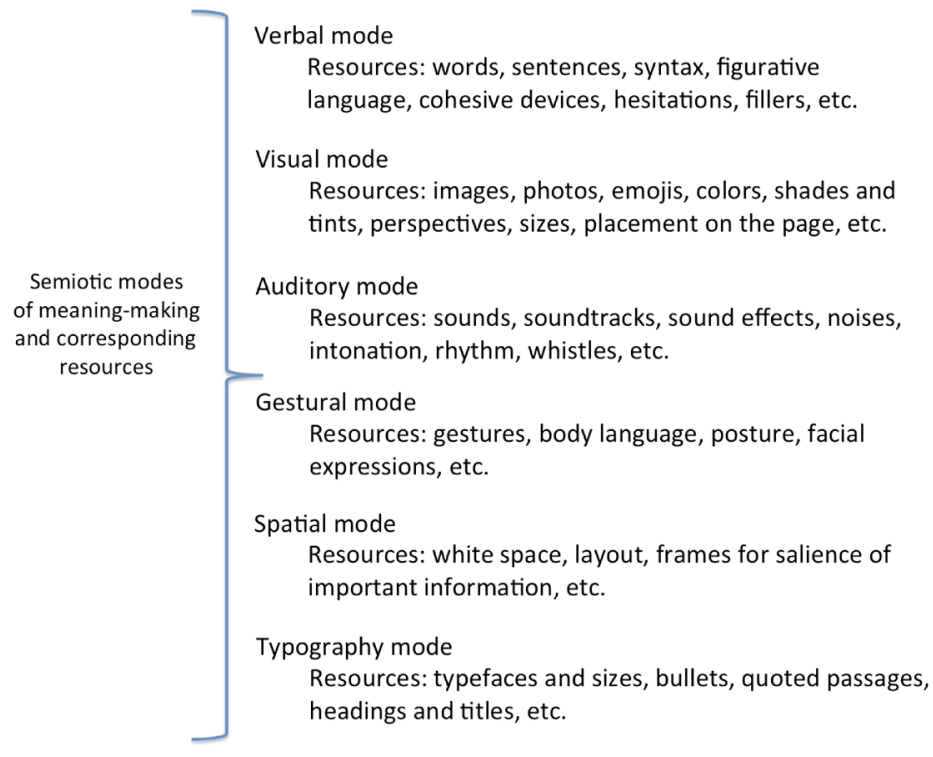

Figure 3. Semiotic modes and corresponding resources (DIAS, 2018a, p. 164)

In sum, writing abstracts involves certain social written conventions for organizing their multimodal patterns that are different from those for writing a book review or an academic article, for example. Abstracts are mostly composed by the 
use of words, sentences and text cohesive ties that give them coherence although their titles and authorship are distinctively highlighted by the use of different typographical features as, for example, capital letters, italics or bold styles, and the centered alignment. University students have to understand and use the rhetorical verbal conventions, move patterns, multimodality, appropriate verb tenses, and their appropriate features of layout for achieving their communicative purposes when writing an abstract for their academic articles. Furthermore, students have to bear in mind that these short pieces of writing function as "previews" or "screening devices" for prospective readers, giving them a road-map for their reading", as quoted by Swales and Feak (2009, p. 2).

\section{THE COMBINED APPROACH TO WRITING}

In this section, I will present the combined approach I recommend in this article for the task of writing in English, its stages and its main objectives. The main goal of this cyclical pedagogical tool is to bring together the strengths of the two traditional writing approaches in the attempt to contribute to learning practices that can benefit students with a targeted support in their writing tasks. The cycle can also have a good effect on teachers who are responsible for teaching academic writing in the university context. I believe that the combined approach can possibly be a way of responding to the challenges involved in facilitating students' writing until they become successful writers.

\subsection{Some background information}

Inspired by White and Arndt's model (1991), the cycle I redesigned (Fig. 5) from the one published in 2004 comprises both process-oriented and genrebased approaches. In going back and forward through the recursive stages of the cycle, students are guided by the multimodal features of different genres, their purposes, grammatical structuring, content and intended audience. Writing is thus a recursive process that includes "knowledge of language, [genres], contexts and audiences" (HYLAND, 2003, p.23). Inspired by this researcher, the combination of approaches depicted in the proposed cycle (Fig. 5) mainly incorporates the following principles:

Respect[ing] students' needs for relevant content through stimulating readings and source materials. 
Support[ting] [...] pedagogies [for writing tasks] with strategies for planning, drafting, and revising texts.

Situat[ing] writing in a conception of audience and link [ing] it to broader social strategies (p.23)

From the perspective of the combined approach, for example, the instructions given above (Fig. 1) can be expanded to be more supportive and encouraging to students' writing in the following way:

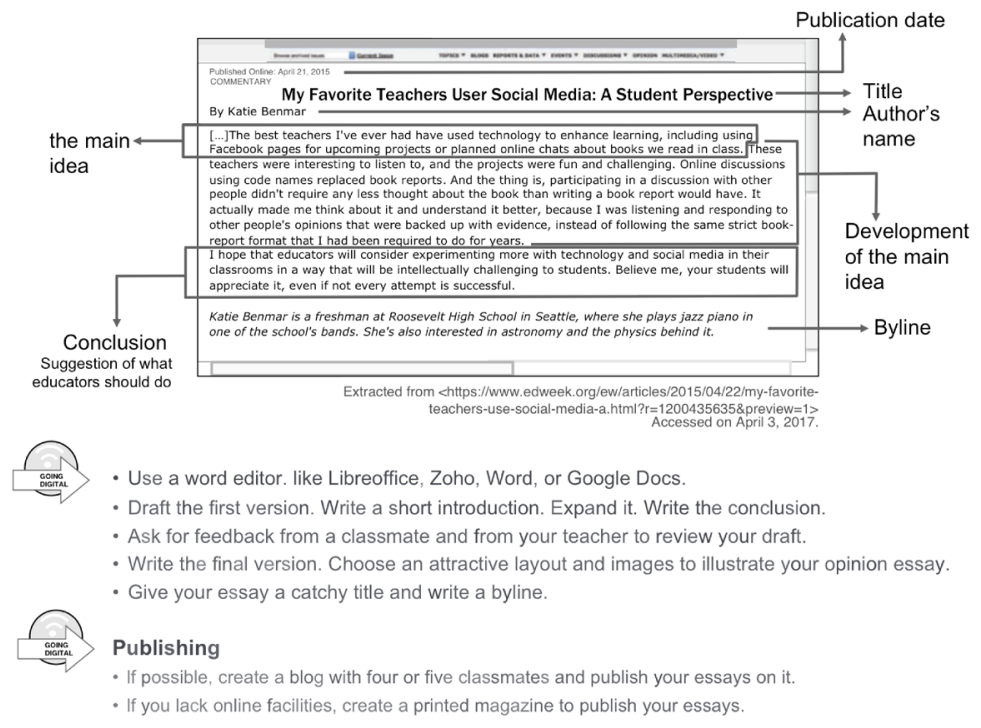

Figure 4. Writing instructions from the perspective of the combined approach (DIAS et al., 2018b, p. 134.

The last stage, publishing, is relevant to make public what students write in English. Publishing will give them a real-world audience such as, teachers of different subjects, students from other classes, and parents, for example. Students become authors and authorship will make them feel a sense of accomplishment for all the effort invested in the process of writing in English.

The combined approach shown in a cyclical fashion (Fig. 5) is made up of various stages, brainstorming, planning, drafts, review, rewritings, editing, final version and "publication", some of which are also accounted for in process-oriented approaches. The editing stage could be included in the cyclical combined approach due to the relatively ease with which writers can edit the texts they write using digital technologies as, for example, text editors, programs for visual representations, 
images in different file formats, and different typographical resources. Today's learners are constantly in touch with multimodal texts and, as such, they have developed their understanding of the use of different semiotic modes to construct meaning. This understanding of multimodality can be transferred to the editing of texts they have to write for communication in different social contexts.

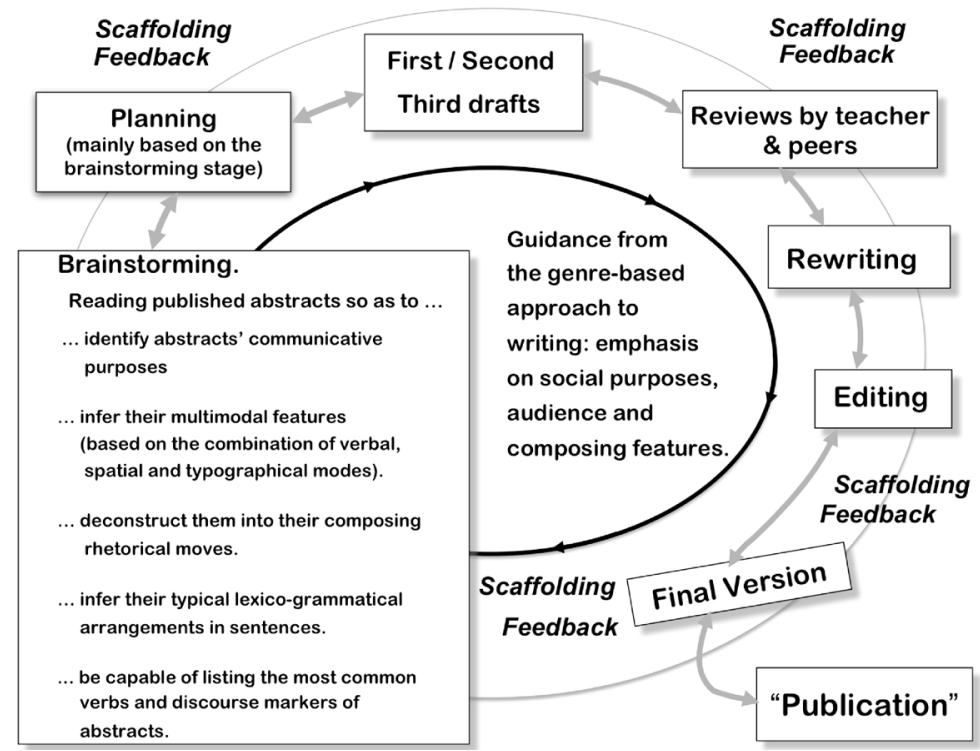

Figure 5. The combined approach.

\subsection{The stages in the combined approach}

As shown in Figure 5, the recursive stages are as follows: Brainstorming, Planning, Drafts-Reviews-Rewriting, Editing, Final Versions and Publication.

\subsubsection{Brainstorming.}

In this stage, students are encouraged to read existing published texts (e.g., abstracts, opinion essays, articles, etc.) as exemplars of both collective social practices and [...] concrete [and] public [...] realizations of these practices" (HYLAND, 2000, p. 1). By reading published samples of a specific genre, students take control over its specific features and will be possibly more capable of writing it in adequate and effective ways. Writing well-formed texts typified / materialized in genres is thus related to the various encounters students have with them through 
reading. Furthermore, the recursive feature of the cycle clarifies that writing is dependent on reading. In fact, reading triggers rewriting during the back and forth processes of improving texts (Fig. 6) and, as such, they are interdependent processes. Indeed, reading-writing-reading-rewriting are closely intertwined in the task of writing texts that comply with their particular social conventions. Moreover, purposes, intended audience, and contextual settings also play important roles in this socially-oriented common tasks in any school / academic setting.

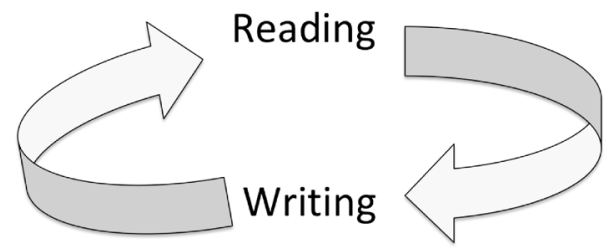

Figure 6. Reading and writing as interdependent processes.

\subsubsection{Planning}

This is a crucial stage in the process of writing any text. Time invested in planning will ensure a successful course of actions during the writing process. Though students can go back to their plans at any point in the cycle and change them, planning will help them envision the multimodal organization of their texts, how they are grammatically patterned and used for certain social purposes and contexts. Students will feel rewarded with their well-written texts that will be read and comprehended by their classmates, teachers, parents and other interested readers.

\subsubsection{Recursive stages}

The back and forth stages of drafting, writing, and rewriting are based on feedback and scaffolding (WOOD; BRUNER; ROSS, 1976) from peers and teachers and also from "mediation [digital] tools" (VYGOSKY, 1978) such as, online dictionaries, grammar explanations, corpora tools, genre rubrics, Google search, spelling correctors, etc. Both feedback and scaffolding are geared by collaboration and social interactions amongst participants to bridge the gap between what they already know about a certain subject and their future knowledge of how to effectively use it (potential learning). This refers to Vygotsky's concept of ZPD (Zone of Proximal Development), that is, «the distance between the actual developmental 
level as determined by independent problem-solving and the level of potential development as determined through problem-solving under adult guidance, or in collaboration with more capable peers» (VYGOSKY, 1978, p. 86). Learning is thus a social endeavor that takes place through interactions in the complex process of meaning making based on the conventions of genres according to their purposes and intended audience.

\subsubsection{Editing}

This is a collaborative process in which feedback and scaffolding play important roles. Hyland (2004, p. 72) reminds us that collaboration during learning involves "the idea that learners working together learn more effectively than individuals working separately" and the notion that "learners working with knowledgeable others develop greater understanding of tasks and ideas". Shared responsibility for expressing meaning is beneficial to the quality of what is done in groups of students. This idea leads us to the notion of collaboration as described by Pallof and Pratt $(2005$, p.4), "when I succeed, we succeed" meaning that members of a group work together in the accomplishment of a task. Digital tools can be useful in this stage and the end-result can be a version that closely resembles exemplars of published genres.

\subsubsection{Publication}

The final stage arrives with the publication of what has been done in collaboration, following the assumptions of the combined approach to writing (Fig. 5). This means that team members recognize that it is time to share their texts with the intended audience. Making texts public is directly related to students' authorship and their empowerment as members of a certain social discursive domain. Publishing can be done on bulletin boards, on the walls of the classroom, in a magazine that binds texts together or in blogs, wikis, or e-books. Brazilian undergraduates can submit what they write (e.g., articles, essays book reviews etc.) to journals to start experimenting with this type of social academic event.

The whole process of planning-drafting-revising is thus guided by the social purposes of genres and intended audience in any social discursive domain, be it academic or not. The writing cycle (Fig. 5) shows the combination of two well-known approaches that may become a visual guidance for students who are composing texts in English. 


\section{THE COMBINED APPROACH AND TEACHING PRACTICES}

In this section, I will weave research and teaching practices based on the aforementioned studies about academic writing in English as well as on the assumptions of the combined approach (Fig. 5). For this purpose, I will discuss the writing pedagogy I designed and implemented for a section of a sixty-hour mandatory course about academic writing in the Faculty of Letters at UFMG. All the teaching activities related to the stages of the cycle will be thoroughly discussed with focus on the multimodal genre "abstract", its social functions, rhetorical moves and audience. First, I will present who the participants are and the context of my classes. Then the teaching practices will be discussed and some examples will be used to clarify the discussion. At the end, I will briefly analyze one of the abstracts written by a group of participating students taking into account its rhetorical moves and multimodal features.

\subsection{Participants and the teaching context}

The participants were freshman enrolled in English One who had just graduated from high school. It was their first encounter with academic genres. The classes took place in a computer lab and all students had access to the Internet. We had our own page in the university Moodle environment and forums, wikis, uploaded files, and chats were used as pedagogical resources. All the course content and learning activities were posted on our Moodle page. The combined approach to writing in English presented in this article (Fig. 5) was used in the process of composing abstracts. Students learned both types of metalanguage: a) the interweaved recursive stages in writing as a process, the importance of feedback, scaffolding, collaboration and b) the social written conventions of abstracts, including their usual rhetorical moves and semiotic features. The main purpose was to assist students in raising awareness of and gaining control over the recursive stages in writing and the multimodal characteristics of abstracts in order to effectively write this academic genre (Fig. 5).

\subsection{Teaching practices}

As shown in Table 2, students went through all the stages of the cycle in the process of writing abstracts in English. For each stage - from brainstorming to publication - there were specific "scaffolding" learning activities to help students in the task of writing abstracts in English. 


\section{Table 2. The stages of the cycle and corresponding teaching practices}

\begin{tabular}{|c|c|}
\hline Brainstorming & $\begin{array}{l}\text { Learning activity 1: Reading abstracts in these Brazilian journals: } \\
\text { Calidoscópio. DELTA. Ilha do Desterro. Linguagem em (Dis)curso. } \\
\text { RBLA. Trabalhos em Linguística Aplicada. } \\
\text { Learning activity 2: Discussing what abstracts are: social purposes, audi- } \\
\text { ence, structuring, and multimodal features. } \\
\text { Learning activity 3: Awareness-raising and understanding of the rhetorical } \\
\text { moves of abstracts, verb tenses, length and their usual semiotic modes of } \\
\text { representation: The verbal, the spatial, and typographical features. } \\
\text { Learning activity 4: Matching each rhetorical move to the question it must } \\
\text { answer. } \\
\text { Learning activity 5: Choosing one of the abstracts they read and showing } \\
\text { its rhetorical moves in a visual way. } \\
\text { Learning activity 6: Creating a list containing the main characteristics of } \\
\text { the multimodal genre "abstract" (Table 5). }\end{array}$ \\
\hline Planning & $\begin{array}{l}\text { Learning activity 7: Planning what and how to write an abstract for the } \\
\text { edited research article "Texts in Printed and Digital Media: facing reading } \\
\text { practices and teaching objects to the training of proficient readers" (Silva, } \\
2017 \text { ), from the Brazilian journal, Signum. } \\
\text { Using the list on the main characteristics of abstracts (Table 5) to guide } \\
\text { their planning. }\end{array}$ \\
\hline $\begin{array}{l}\text { Drafting-rewriting- } \\
\text { redrafting-rewriting. }\end{array}$ & $\begin{array}{l}\text { Learning activity } 8 \text { : Writing the abstract for Silva's article following the } \\
\text { cyclical stages of the writing cycle as well as considering the characteristics } \\
\text { of the multimodal genre "abstract". } \\
\text { Sources of support } \\
\text { The list on abstracts created by the students (Table 5). A Youtube } \\
\text { video on how to write abstracts (CLAWSON, 2016). Collaboration } \\
\text { in pairs. Feedback. Scaffolding from the teacher, peers and digital } \\
\text { tools. Online dictionaries. COCA (Corpus of Contemporary Ameri- } \\
\text { can English). Websites specialized in academic writing. }\end{array}$ \\
\hline Publication & $\begin{array}{l}\text { Learning activity 9: Publishing their abstracts on a Moodle Forum. } \\
\text { Learning activity 10: Reading each other's abstracts and commenting on } \\
\text { them. }\end{array}$ \\
\hline
\end{tabular}




\subsubsection{Brainstorming}

This stage comprised six learning activities (Table 2). The purpose of Learning Activity 1, for example, was to give the participating students the opportunity to read different abstracts in some of the Brazilian most renowned journals, whose addresses were posted on our Moodle page. After reading different exemplars of published abstracts, we held a debate in which I encouraged them to talk about what they had noticed about the abstracts they read. This is related to the pedagogical practices in Activity 2. Then, the students gathered in groups to work collaboratively and the main task was: list the main parts of this multimodal genre. The hint was: pay attention to the sentences, count them and find out what type of information they are giving about the research articles that follow the abstracts. When involved with Learning Activity 3, participants were able to recognize the usual parts (purpose-methodology-results-conclusion) and some of them discovered the right terminology, rhetorical moves, with the assistance of a quick Google search. In sum, three main assumptions of the combined approach (Fig. 5) are revealed in this short analysis: the importance of reading for raising students' awareness of genre characteristics; the relevance of collaboratively working together, and the supportive help given by digital tools. One of the participants' comments was as follows:

Reading various abstracts helped me recognize the regularity of terms, especially verbs, together with the following words, purpose, objective, results, analysis, teachers, students, [among others,] helped me understand what I read (Anonymous).

In Learning Activity 4, the participating students were asked to match the rhetorical moves to their corresponding implied questions, a learning task I created based on Swales and Freak (Fig. 7). The main purpose of this task was to encourage a problem-solving analysis and solution. At this point, I realized that the students began to gain more control over the written organization of abstracts and how they were structured. It is then possible to argue that this control would empower them to write well-formed exemplars of this multimodal genre in academic communicative situations that require its use. 
Matching activity: Match the rhetorical moves to the questions they answer.
Move 1
(1) Background/ Introduction situation
Move 2
(2) Present research / purpose
(4) What was discovered?
Move 3
( 3 ) Methods / Materials / Subjects/ Procedures
( 3 ) How was it done?
Move 4
(4) Results / findings
(1) What do we know about the topic?
Move 5
( 5 ) What do the findings mean?
(5) Discussion / Conclusion
(2) Why is this topic important?

Figure 7. Matching (Adapted from SWALES; FEAK, p.5)

In Learning activity 5, participating students were asked to visually show the rhetorical moves (Fig. 8) in the abstracts they had read. One of the visual displays created by a group of students to show the abstract moves follows below. The participants also noticed that the optional move, background information or introduction, was omitted from this abstract (BAMBIRRA, 2017). Indeed, Tseng's research reminds us that abstracts in the field of Applied Linguistics tend to be structured in a four-move sequence (Purpose-Method-Product-Conclusion).

\begin{abstract}
Move 1 - Purpose: [This paper seeks to discuss the interrelations between the motivation of an English teacher at a public federal high school in Brazil and that of her students from a dynamic systems perspective.] Move 2 Methodology: [Three teachers' oral narratives and 14 students' logbook entries were used for the data analysis. The teacher's descriptions and comments on her pedagogical practice were compared to the students' impressions and motivational levels in an attempt to understand this English classroom-system motivational dynamics and self-organization processes, focusing on how this teacher's and her students' motivation co-adapt and soft-assemble, influencing and being influenced by the context.] Move 3 - Results: [The results seem to confirm not only that student motivation and teacher motivation are deeply interrelated, but also that they interact organically and continually, revealing that the context is contingent.]
\end{abstract}

Figure 8. A visual display of rhetorical moves in an abstract

After going through all learning activities about abstracts that were always followed by discussions in class, the students realized this genre has a particular multimodal organization, a restricted use of verbal tenses in the present/past time and words that are frequently used such as, results, purpose, teaching, learning, among others. Then, in Learning activity 6 , they were asked to create a list (Table 
3) with their specificities. This list was used as a scaffolding tool during the process of writing their abstracts.

\section{Table 3. List of the main characteristics of abstracts}

- The five rhetorical moves are not always used.

- The moves are not sequenced the same way in the abstracts. Some follow the conventional "purpose-methodology-results-conclusion" sequence but some do not.

- Verbs are usually in the present time (e.g., simple present tense) and some in the past.

- Titles are emphasized with the use of capital letters (or other typological resource) and are usually centered.

- Authors' names are followed by their institutional affiliation and are either aligned to the right or centered.

- Authors' e-mails are usually given as a footnote, at the bottom of the first page of the article.

- Abstracts are short and concise.

- Keywords are always mentioned in a sequence, at the end of the abstract.

- Abstracts, their titles and keywords are always in two languages, English and Portuguese.

- An abstract written in English appears first, followed by the one in Portuguese, when the article is written in English.

- An abstract written in Portuguese appears first, followed by the one in English, when the article is written in Portuguese.

\subsection{Planning the writing}

Participating students in my class were handed an edited version of the article "Texts in printed and digital media: facing reading practices and teaching objects to the training of proficient readers" (SILVA, 2017) from which the abstract had been deleted. They had to read the article and were asked to write an abstract to go along with it. They had to plan their courses of action for the writing process and the main supportive tools were: understanding of the rhetorical move sequence of abstracts, the title of the article; feedback from peers and the teacher; online dictionaries, the "Linguee" dictionary that is specially useful for undergraduates whose first language is not English. 
Before starting their planning, participating students in groups of two had to choose two abstracts, evaluate them and provide a short oral report about their social written conventions to the whole class. The purpose of this report was to give me the opportunity to assess what they had learned about this genre. I could gauge if they had had any difficulty doing this task, but all went well during the oral report.

\subsection{Drafting-writing-revising cycle}

In the process of writing their abstracts, participating students could count on the following supportive tools:

Feedback and scaffolding from peers and their teacher.

Scaffolding from the list created by them (Table 3).

Scaffolding from digital tools: online dictionaries, including:

"Linguee", an English-Portuguese dictionary, web search of any type;

COCA (Corpus of Contemporary American English) for consulting the context for the words they wanted to use;

a Youtube video about how to create an abstract (CLAWSON, 2016);

Websites specialized in academic writing (e.g., The Purdue Online Writing Lab; The North Caroline and the Monash University Writing Centers).

As their teacher, I could observe that the task was not an easy one and students had to struggle to compose their abstracts. The structuring of the sentences was time consuming and they had to frequently consult the supportive tools they had at their disposal and count on my feedback. It was clear that they were collaborating with each other and negotiation within the groups was one of the strategies used by them. I noticed that they read the article several times and highlighted relevant information for their abstracts.

\subsection{Editing their abstracts}

While shaping the language in the rhetorical moves to comply with the social written conventions of abstracts, the students also used the list they had created regarding spatial organization and typographical features (Table 3). I could observe that they worked diligently in collaboration with each other. 


\subsection{Final versions and publication}

They published their abstracts in a Moodle Forum that was created for this end. I can say that the abstracts were well formed and adequately composed in terms of the social written conventions of this academic genre.

In general, all abstracts were structured in the conventional sequence (purposemethodology-product-conclusion) and showed a good development of ideas giving them adequate coherence. Out of the ten abstracts, six were very well composed, while the other four showed some deviations from the conventional way of writing abstract. These four also lacked quality due to students' miscomprehension of the article on which the abstracts had to be written. There were minor grammatical mistakes but improper use of vocabulary did not take place. As an example, an abstract is shown in Table 4. I highlighted the moves to clarify my analysis that follows below.

\section{ANALYSIS}

Different from what Tseng (2011) reminds us about abstracts in the field of Applied Linguistics, the one in Table 4 includes the five rhetorical moves in their composition as acknowledged by Hyland (Table 1). It presents some background information (that is usually an optional move), the purpose of the article, the methodology, the product and the conclusion. The moves related to the methodology and to the product, however, could have been more detailed. In the methodology move, the research method should have been mentioned. In the move concerning the product or results, the main findings have been presented although the sentence, "the researcher gets to the conclusion ..." is misleading and should not have been used. The move related to the conclusion is adequately composed. It extends the findings of the investigation to the pedagogical need of developing reading comprehension questions that go beyond simple copies of information in order to include the social aspects that are intertwined in the texts students read in class. 
Table 4. An abstract for Silva's article

\title{
Texts in Printed and Digital Media: facing reading practices and teaching objects to the training of proficient readers*
}

\begin{abstract}
Move one: background information]. Nowadays, beyond the use of books for reading practices for learning, people are also using content found on the Internet. [Move two: purpose]. This paper aims to analyze if these frequently used texts need new configurations for the formation of communicatively competent readers. [Move three: methodology]. For the print media, the author collected texts from the textbooks used in the $8^{\text {th }}$ grade of the Brazilian school system that addressed the theme of racial prejudice. For the digital media the data were composed of an image of the journalist Maria Júlia Coutinho who was a victim of racism and comments posted on social media about her, and the transcription of a news report published by the TV anchor William Bonner. [Move four: product]. After analyzing the data, the researcher gets to the conclusion that in the print media, the questions in the book do not problematize the relationship between social inequality and the racial issue. In the digital media, the examples show ways of producing meaning in which the arguments that support readers' position are related to various experiences, individual and collective ones, influenced by sociocultural contexts. [Move five: conclusion]. By that, the author concludes that there is a need go chance (sic) the configurations in the texts analyzed for the formation of communicatively competent readers, using methods that show the importance of social aspects beyond reading comprehension for doing activities.

Keywords: critical reading practices; print and digital media; racial issues.

*SILVA, W.M. (2017). Texts in printed and digital media: facing reading practices and teaching objects to the training of proficient readers. Signum: Estudos da Linguagem. v. 20, n 1, pp. 81 109.

**Written by a group of students enrolled in English One.
\end{abstract}

As far as the multimodal aspects are concerned, the title is in bold and centered. A symbol was inserted to indicate the source of the article. The words, abstract and keywords are in bold to highlight them. There is a space between the title and the beginning of the abstract - a spatial mode that has to be included according to the social multimodal conventions of this genre.

In sum, it seems that the combined approach can assist students in gaining control over social genre conventions in a cyclical fashion. The participants had opportunities to write abstracts adequately through feedback and scaffolding from peers and the teacher, use the supportive help given by digital tools, edit the final versions in a multimodal way and publish them. The notion of working together in collaboration is also a key concept in this writing pedagogy. Shared responsibility for expressing meaning is beneficial to all participants for the quality of their work. Though time consuming due to the engagement with the tasks in the various stages, undergraduates could adequately write the academic multimodal genre "abstract" following the assumptions of the combined approach presented in this article. 


\section{CONCLUDING REMARKS}

The purpose of this article was to gather research on academic writing and practical knowledge about composing abstracts in the attempt to propose a combination of genre-based and process-oriented approaches to writing in English. I believe that the combined approach as presented in this article is adequate to students' writing the multimodal genre "abstracts" in the academic settings. Additionally, this approach can be of help to professors and university students when dealing with the demanding task of writing in English. It will also be useful to all English teachers who want to involve their students in a meaningful way of composing academic genres in a domain whose motto is "publish or perish".

\section{REFERENCES}

BAMBIRRA, R. (2017). Motivational dynamics in English classes at a Brazilian public school. Revista Brasileira de Linguística Aplicada. v. 17; n 2, pp. 219-246.

BARBOSA, E.R. (2016). Navegando no universo surdo: a multimodalidade a favor do ensino de português como segunda língua em um curso EAD. Dissertação de Mestrado em Estudos Linguísticos, UFMG

BATHIA, V.K. (1993). Analysing genre: language use in professional settings. London: Longman.

BAKHTIN, M.M. (2003). Estética da criação verbal. São Paulo: Martins Fontes.

BEREITER, C.; SCARDAMALIA, M.(1987). The psychology of written composition. Hillsdale: Erlbaum.

CAN, S., KARABACAK, E., \& QIN, J. (2016). Structure of Moves in Research Article Abstracts in Applied Linguistics. Publications. v. 4; $\mathrm{n}^{\circ}$ 23, pp. 1-16.

CASTRO, V.C. (2015) Turn on your mobile devices In the English classes: uso do twitter como ferramenta de colaboração no processo de escrita. Dissertação de Mestrado em Estudos Linguísticos, UFMG.

CHALAK, A., \& NOROUZI, Z. (2013). Rhetorical moves and verb tense in abstracts: A comparative analysis of American and Iranian academic writing. International Journal of Language Studies. v. $7 ; \mathrm{n}^{\circ} 4$, pp. 101-110. 
CLAWSON, C. (2016). How to Write an Abstract. Retrieved from: <https://www.youtube. $\mathrm{com} /$ watch?v $=\mathrm{H} 50 \mathrm{ktdKlcnU}>$

DUARTE, M.A.T.M. (2017). Aproximando teoria e prática: A utilização da abordagem pedagógica Sala de Aula Invertida para o ensino do gênero textual biografia em um curso de inglês para fins específicos. Dissertação de Mestrado em Estudos Linguísticos, UFMG.

DIAS, R. (2018a). Entrevista. Polifonia. v. 25; n 37, pp. 160-170.

DIAS, R. et al. (2018b). New High Up: Inglês para o Ensino Médio. São Paulo: Macmillan.

DIAS, R. et al. (2005). Proposta Curricular de Lingua Estrangeira do Estado de Minas Gerais (Manuscrito).

DIAS, R. et al. (2004). A produção textual como processo interativo no contexto do ensino e aprendizagem de línguas estrangeiras. Matraga. v. 1; n 16, pp. 203-218.

HYLAND, K. (2008). Writing theories and writing pedagogies. Indonesian Journal of English Language Teaching. v. 4; $\mathrm{n}^{\mathrm{O}} 2$, pp. 91-110.

HYLAND, K. (2007). Genre pedagogy: Language, literacy and L2 writing instruction. Journal of Second Language Writing. v. 16; n 3 , pp. 148-164

HYLAND, K. (2004). Genre and Second Language Writing. Michigan: Michigan University Press.

HYLAND, K. (2003). Second language writing. Cambridge: Cambridge University Press.

HYLAND, K. (2002). Teaching and researching writing. Harlow: Longman.

HYLAND, K. (2000). Disciplinary Discourses: Social Interactions in Academic Writing. Ann Arbor: Michigan University Press.

KRESS, G.; VAN LEEUWEN, T. (2006). Reading Images: the Grammar of Visual Design. London; New York: Routledge.

MORIN, E. (2011). Introdução ao pensamento complexo. 4ª Ed. Porto Alegre: Sulina.

PALLOFF, R.M., \& PRATT, K. (2005). Collaborating online: learning together in community. San Francisco: Jossey-Bass.

RAIMES, A. (1983). Techniques in teaching writing. New York: Oxford University Press. 
SILVA, W.M. (2017). Texts in printed and digital media: facing reading practices and teaching objects to the training of proficient readers. Signum: Estudos da Linguagem. v. $20 ; \mathrm{n}^{\mathrm{O}} 1$, pp. 81-109.

SWALES, J.M., \& FEAK, C.B. (2009). Abstracts and the writing of abstracts. Michigan: The University of Michigan Press.

TSENG, F.P. (2011). Analyses of move structure and verb tense of research article abstracts in Applied Linguistics Journals. International Journal of English Linguistics. v. 1; $\mathrm{n}^{\mathrm{O}} 2$, pp. 27-39.

VYGOTSKY, L. S. [1978] (1998). A formação social da mente. 6ª Ed. São Paulo: Martins Fontes.

WHITE, R.; ARNDT, V. (1991). Process writing. London; New York: Longman.

WOOD, D.J.; BRUNER, J. S.; ROSS, G. (1976). The role of tutoring in problem solving. Journal of Child Psychiatry and Psychology. v. 17; $\mathrm{n}^{\mathrm{O}} 2$, pp 89-100.

Recebido: 29/09/2019

Aceito: 30/01/2020

Publicado: 2/03/2020 